\title{
Examination of Local Anti-inflammatory Activities of New Steroids, Hemisuccinyl Methyl Glycolates
}

\author{
Toshio SuzukI, ${ }^{*, a}$ Etsuko SAto, ${ }^{a}$ Hitoshi TAdA,${ }^{a}$ and Yoichi ToJimA ${ }^{b}$ \\ Department of Pharmaceutical Science, Akita University Hospital, ${ }^{a}$ Hondo 1-1-1, Akita 010-8543, Japan and Ohta \\ Pharmaceutical Co., Ltd., ${ }^{b}$ 9-19 Tomizawa, Nihonbashi, Chuoh-ku, Tokyo 103-0006, Japan. \\ Received November 16, 1998; accepted May 20, 1999
}

To overcome the side effects of steroids, novel steroid-17-yl methyl glycolates with succinyl group at C-20, derived from prednisolone and dexamethasone were prepared based on a concept of the antedrug. Their topical anti-inflammatory activity and systemic effects were evaluated through croton oil-induced ear edema and paper disk granuloma bioassay. Among them, (20S)-succinyl dexamethasone derivatives (7 and 11) indicated more potent anti-inflammatory activity than the parent dexamethasone and did not show corticosteroidal side effects of thymic, adrenal involution or body weight loss. Both 7 and 11 were immediately metabolized into active compound 3 and this metabolite was eliminated with mean half-lives of 0.786 to $0.866 \mathrm{~h}$ in rat serum. Our findings suggest that these two compounds might be candidates as the novel steroids, and that that introduction of the succinyl group into the methyl glycolates at $\mathrm{C}-20$ is useful to avoid suppression of organs due to the side effects of corticosteroids.

Key words prednisolone; dexamethasone; antedrug; corticosteroid; anti-inflammatory activity; topical steroid

Succinyl glucocorticoids are rapidly hydrolyzed by esterase in human serum to release parent glucocorticoids which express anti-inflammatory activities. ${ }^{1-3)}$ Esterification of the glucocorticoid alcohols with succinic acid and phosphoric acid results in water-soluble derivatives of the steroids and makes the use of intravenous administration possible. However, the adverse systemic effect of using glucocorticoids both in high doses for shock and long-term administration for chronic inflammatory diseases has been a limiting factor. To overcome these side effects, a concept antedrug was introduced by Lee and Soliman. ${ }^{4}$-7) The term antedrug was defined as a locally-effective drug which shows strong pharmacological action at the site of application, and when it enters the systemic circulation immediately changes to the inactive form, resulting in no systemic action. ${ }^{4)}$ According to this concept, we prepared some of the steroid-17-yl methyl glycolates to develop a colonic mucosa-specific steroid proantedrug for oral treatment of ulcerative colitis. ${ }^{8)}$

In our continuous efforts to find a more effective steroidal antedrug, we synthesized some of the succinyl derivatives of steroid-17-yl methyl glycolates in the hope that an increase of lipophilia of the steroids might enhance the permeability of the drugs into the epidermal layer, ${ }^{9)}$ and that thus it might easily reach and accumulate at the inflammatory site. Both succinyl and methyl ester groups might be rapidly removed by the enzymatic hydrolysis in $\operatorname{skin}^{10)}$ and converted to inactive forms when they enter the systemic circulation without systemic action, although anti-inflammatory activities of the succinylated steroids have not yet been reported.

In the present study, we report anti-inflammatory activities of steroid-17-yl hemisuccinyl methyl glycolates and the influence of administration of their glycolates on adrenal and thymus in rats.

\section{CHEMISTRY}

$(20 S / R)$-Steroid-17-yl methyl glycolates $(\mathbf{1}, \mathbf{2})^{4)}$ and (3, 4) ${ }^{11)}$ were prepared from prednisolone and dexamethasone, respectively, according to the method previously describ-

* To whom correspondence should be addressed. ed. ${ }^{8,12,13)}$ Each succinic acid derivative $(\mathbf{5}, \mathbf{6}, \mathbf{7}$ and 8 ) was synthesized by the reaction of the corresponding methyl glycolate $(1,2,3$ and 4$)$ with succinic anhydride in dry pyridine, respectively. Treatment of each succinic acid $(\mathbf{5}, \mathbf{6}, \mathbf{7}$ and $\mathbf{8})$ with chlorotrimethylsilane in absolute methanol gave the corresponding methyl ester $(9,10,11$ and 12), respectively, hydrolysis of 3 with $2 \mathrm{~N}$ potassium hydroxide in methanol provided the carboxylic acid (13) .

\section{MATERIALS AND METHODS}

Materials Prednisolone and dexamethasone were obtained from Nacalai Tesque, Inc. (Kyoto, Japan). All the reagents used in this study were reagent grade commercial products and were used without further purification. Purity of synthesized steroids was checked by HPLC using a Waters $8 \mathrm{C} 1810 \mu$ column with $20 \mathrm{~mm}$ phosphoric acid-acetonitrile $(45: 55 \mathrm{v} / \mathrm{v})$. All compounds indicated a single peak in the chromatogram.

Experimental All reactions were performed under a nitrogen atmosphere. Specific rotations were measured with a PM-101 polarimeter. ${ }^{1} \mathrm{H}-\mathrm{NMR}$ spectra were taken for solutions in deuteriochloroform (tetramethylsilane as an internal standard) on a JEOL JNM-EX-270 instrument. IR spectra were recorded on a Jasco IR-810 spectrophotometer. Mass spectra were obtained on a JEOL JMS-OISG-2 spectrometer. Half-lives of the tested compounds in serum were determined by HPLC, which was used a Waters 600E pump with a Waters 484 tunable absorbance detector. All products described in the Experimental Section were homogeneous in TLC and HPLC.

(20S/R)-11 $\beta$, 17,20-Trihydroxy-20-methoxycarbonyl-3ox0-1,4-pregnadien-3-one 20-Succinate (5/6) A mixture of methyl prednisolonates (1) (145 mg, $0.373 \mathrm{mmol})$ and succinic anhydride $(224 \mathrm{mg}, 2.24 \mathrm{mmol})$ in dry pyridine $(1.3 \mathrm{ml})$ was stirred for $3 \mathrm{~h}$ at $70^{\circ} \mathrm{C}$. The reaction was quenched by the addition of water and an excess of pyridine was evaporated in vacuo to leave a residue which was acidified with $10 \% \mathrm{H}_{2} \mathrm{SO}_{4}$ and extracted with ethyl acetate. The extract was 

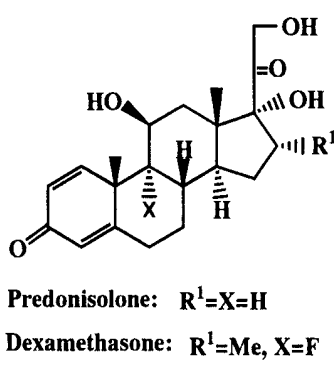
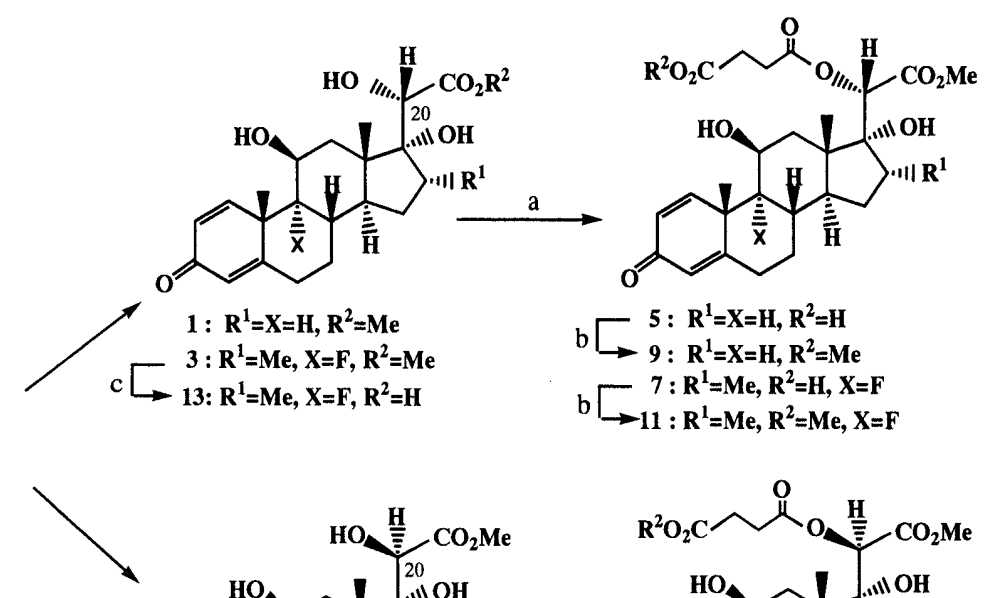

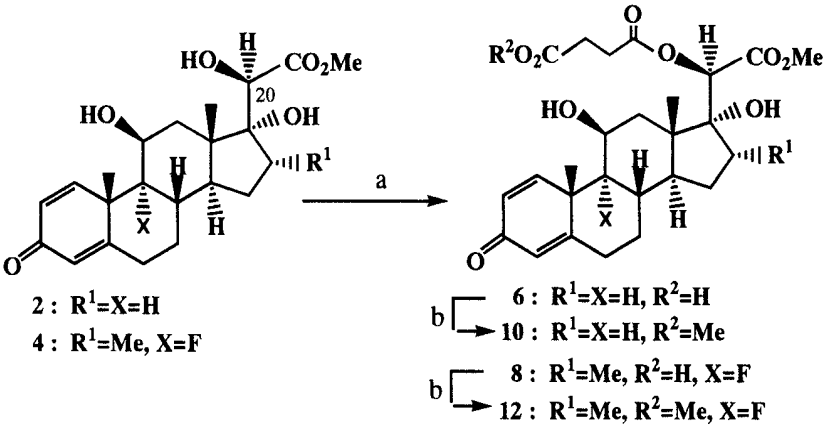

a: succinic anhydride, dry pyridine, $60-70^{\circ} \mathrm{C}$. b: $\mathrm{Me}_{3} \mathrm{SiCl}$, by dry $\mathrm{MeOH}$, r.t. c: $2 \mathrm{~N} \mathrm{KOH}, \mathrm{MeOH}$, r.t.

Chart 1

washed with brine and dried $\left(\mathrm{MgSO}_{4}\right)$. Evaporation of the solvent left a residue which was chromatographed on silica gel. The elution with $\mathrm{CHCl}_{3}-\mathrm{MeOH}(97: 3 \mathrm{v} / \mathrm{v})$ provided 5 (185 mg, quantitative yield), $[\alpha]_{\mathrm{D}}+51.5^{\circ}(c=0.101, \mathrm{MeOH})$. IR $\left(\mathrm{CHCl}_{3}\right) \mathrm{cm}^{-1}: 3600-3300(\mathrm{OH}), 1744,1659(\mathrm{C}=\mathrm{O})$, $1620,1600(\mathrm{C}=\mathrm{C}) .{ }^{\mathrm{l}} \mathrm{H}-\mathrm{NMR}\left(\mathrm{CDCl}_{3}+\mathrm{CD}_{3} \mathrm{OD}\right) \delta: 1.01(\mathrm{~s}$, $3 \mathrm{H}, \mathrm{Me}), 1.45(\mathrm{~s}, 3 \mathrm{H}, \mathrm{Me}), 3.75\left(\mathrm{~s}, 3 \mathrm{H}, \mathrm{CO}_{2} \mathrm{Me}\right), 4.42(\mathrm{dd}$, $1 \mathrm{H}, J=6,3 \mathrm{~Hz}, 11-\mathrm{H}), 5.31(\mathrm{~s}, 1 \mathrm{H}, 20-\mathrm{H}), 6.03(\mathrm{~d}, 1 \mathrm{H}, J=2$ $\mathrm{Hz}, 4-\mathrm{H}), 6.27$ (dd, $1 \mathrm{H}, J=10,2 \mathrm{~Hz}, 2-\mathrm{H}), 7.38$ (d, $1 \mathrm{H}, J=10$ $\mathrm{Hz}, 1-\mathrm{H}$ ). HRMS $\left(\mathrm{M}^{+}-18\right) \mathrm{m} / \mathrm{z}: 472.2098$ (Calcd for $\mathrm{C}_{26} \mathrm{H}_{32} \mathrm{O}_{8}:$ : 472.2098).

Compound $6\left(173 \mathrm{mg}\right.$, quantitative yield): $[\alpha]_{\mathrm{D}}+37.3^{\circ}$ $(c=0.102, \mathrm{MeOH})$. IR $\left(\mathrm{CHCl}_{3}\right) \mathrm{cm}^{-1}: 3600-3300(\mathrm{OH})$, 1740, $1659(\mathrm{C}=\mathrm{O}), 1620,1603(\mathrm{C}=\mathrm{C}) .{ }^{1} \mathrm{H}-\mathrm{NMR}\left(\mathrm{CDCl}_{3}+\right.$ $\left.\mathrm{CD}_{3} \mathrm{OD}\right) \delta: 1.20(\mathrm{~s}, 3 \mathrm{H}, \mathrm{Me}), 1.46(\mathrm{~s}, 3 \mathrm{H}, \mathrm{Me}), 3.75(\mathrm{~s}, 3 \mathrm{H}$, $\mathrm{CO}_{2} \mathrm{Me}$ ), 4.37 (dd, $\left.1 \mathrm{H}, J=6,3 \mathrm{~Hz}, 11-\mathrm{H}\right), 5.08(\mathrm{~s}, 1 \mathrm{H}, 20-$ H), $6.02(\mathrm{~d}, 1 \mathrm{H}, J=2 \mathrm{~Hz}, 4-\mathrm{H}), 6.25(\mathrm{dd}, 1 \mathrm{H}, J=10,2 \mathrm{~Hz}, 2-$ H), $7.30(\mathrm{~d}, 1 \mathrm{H}, J=10 \mathrm{~Hz}, 1-\mathrm{H})$. HRMS $\left(\mathrm{M}^{+}-18\right) \mathrm{m} / \mathrm{z}$ : 472.2097 (Calcd for $\mathrm{C}_{26} \mathrm{H}_{32} \mathrm{O}_{8}:$ 472.2097) was obtained by a reaction of $2(137 \mathrm{mg})$ and succinic anhydride $(211 \mathrm{mg})$ in dry pyridine $(1.3 \mathrm{ml})$ under the conditions described above.

(20S/R)-9-Fluoro-11 $\beta, 17,20$-trihydroxy-20-methoxycarbonyl-1,4-pregnadien-3-one 20-Succinate (7/8) (20S)Succinic acid (7) (114 mg, quantitative yield); $[\alpha]_{D}+43.6^{\circ}$ $(c=0.11, \mathrm{MeOH})$. IR $\left(\mathrm{CHCl}_{3}\right) \mathrm{cm}^{-1}: 3600-3300(\mathrm{OH})$, 1742, $1664(\mathrm{C}=\mathrm{O}), 1623,1607(\mathrm{C}=\mathrm{C}) .{ }^{1} \mathrm{H}-\mathrm{NMR}\left(\mathrm{CDCl}_{3}\right) \delta$ : 0.82 (d, $3 \mathrm{H}, J=6.9 \mathrm{~Hz}, \mathrm{Me}), 1.06$ (s, $3 \mathrm{H}, \mathrm{Me}), 1.55(\mathrm{~s}, 3 \mathrm{H}$, $\mathrm{Me}), 3.74\left(\mathrm{~s}, 3 \mathrm{H}, \mathrm{CO}_{2} \mathrm{Me}\right), 4.23(\mathrm{~d}, 1 \mathrm{H}, J=9.6 \mathrm{~Hz}, 11-\mathrm{H})$, $5.18(\mathrm{~s}, 1 \mathrm{H}, 20-\mathrm{H}), 6.11(\mathrm{~d}, 1 \mathrm{H}, J=1.65 \mathrm{~Hz}, 4-\mathrm{H}), 6.32(\mathrm{dd}$, $1 \mathrm{H}, J=10,1.65 \mathrm{~Hz}, 2-\mathrm{H}), 7.29(\mathrm{~d}, 1 \mathrm{H}, J=10 \mathrm{~Hz}, 1-\mathrm{H})$. HRMS $\left(\mathrm{M}^{+}-18\right) \mathrm{m} / \mathrm{z}$ : 504.2160 (Calcd for $\mathrm{C}_{27} \mathrm{H}_{33} \mathrm{FO}_{8}$ $504.2160)$ was obtained by a reaction of $\mathbf{3}(90 \mathrm{mg})$ and succinic anhydride $(129 \mathrm{mg})$ in dry pyridine $(0.6 \mathrm{ml})$ under the same conditions as described above.

$(20 R)$-Succinic acid (8) $\left(93.5 \mathrm{mg}\right.$, quantitative yield); $[\alpha]_{\mathrm{D}}$ $+27.2^{\circ}(c=0.081, \mathrm{MeOH}) . \mathrm{IR}\left(\mathrm{CHCl}_{3}\right) \mathrm{cm}^{-1}: 3600-3300$ $(\mathrm{OH}), 1740,1659(\mathrm{C}=\mathrm{O}), 1620,1603(\mathrm{C}=\mathrm{C}) .{ }^{1} \mathrm{H}-\mathrm{NMR}$ $\left(\mathrm{CDCl}_{3}\right) \delta: 1.08(\mathrm{~d}, 3 \mathrm{H}, J=6.9 \mathrm{~Hz}, \mathrm{Me}), 1.22(\mathrm{~s}, 3 \mathrm{H}, \mathrm{Me})$, $1.55(\mathrm{~s}, 3 \mathrm{H}, \mathrm{Me}), 3.72\left(\mathrm{~s}, 3 \mathrm{H}, \mathrm{CO}_{2} \mathrm{Me}\right), 4.23(\mathrm{~d}, 1 \mathrm{H}, J=10.9$ $\mathrm{Hz}, 11-\mathrm{H}), 5.04(\mathrm{~s}, 1 \mathrm{H}, 20-\mathrm{H}), 6.12(\mathrm{~d}, 1 \mathrm{H}, J=1.65 \mathrm{~Hz}, 4-\mathrm{H})$, $6.33(\mathrm{dd}, 1 \mathrm{H}, J=10,1.65 \mathrm{~Hz}, 2-\mathrm{H}), 7.25(\mathrm{~d}, 1 \mathrm{H}, J=10 \mathrm{~Hz}, 1-$ H). HRMS $\left(\mathrm{M}^{+}-18\right) \mathrm{m} / \mathrm{z}$ : 504.2162 (Calcd for $\mathrm{C}_{27} \mathrm{H}_{33} \mathrm{FO}_{8}$ $504.2160)$ was obtained by a reaction of $4(74.2 \mathrm{mg})$ and succinic anhydride $(106 \mathrm{mg})$ in dry pyridine $(0.7 \mathrm{ml})$ under the same conditions as described above.

Methyl(20S/R)-11 $\beta, 17,20$-trihydroxy-20-methoxycarbonyl-1,4-pregnadien-3-one 20-Succinate (9/10) Chlorotrimethylsilane $(94.5 \mathrm{mg}, 0.87 \mathrm{mmol})$ was added dropwise to a stirred solution of (20S)-succinic acid (5) $(213 \mathrm{mg}, 0.435$ $\mathrm{mmol})$ in dry $\mathrm{MeOH}(6.5 \mathrm{ml})$. After being stirred for $2 \mathrm{~h}$ at room temperature under nitrogen, the solution was evaporated to leave a residue which was diluted with chloroform. The extract was washed with brine, dried $\left(\mathrm{MgSO}_{4}\right)$ and then evaporated to leave a residue which was chromatographed on silica gel. The elution with $\mathrm{CHCl}_{3}-\mathrm{MeOH}(99: 1 \mathrm{v} / \mathrm{v})$ provided $9(187 \mathrm{mg}, 85.4 \%),[\alpha]_{\mathrm{D}}+68.4^{\circ}\left(c=1.55, \mathrm{CHCl}_{3}\right)$. IR $\left(\mathrm{CHCl}_{3}\right) \mathrm{cm}^{-1}: 3550(\mathrm{OH}), 1736,1660(\mathrm{C}=\mathrm{O}), 1620,1600$ $(\mathrm{C}=\mathrm{C}) .{ }^{1} \mathrm{H}-\mathrm{NMR}\left(\mathrm{CDCl}_{3}\right) \delta: 1.03(\mathrm{~s}, 3 \mathrm{H}, \mathrm{Me}), 1.48(\mathrm{~s}, 3 \mathrm{H}$, $\mathrm{Me}), 3.71,3.75\left(\mathrm{~s}\right.$, each $\left.3 \mathrm{H}, \mathrm{CO}_{2} \mathrm{Me}\right), 4.45-4.47(\mathrm{~m}, 1 \mathrm{H}$, $11-\mathrm{H}), 5.37(\mathrm{~s}, 1 \mathrm{H}, 20-\mathrm{H}), 6.03(\mathrm{~d}, 1 \mathrm{H}, J=2 \mathrm{~Hz}, 4-\mathrm{H}), 6.27$ (dd, $1 \mathrm{H}, J=10,2 \mathrm{~Hz}, 2-\mathrm{H}), 7.30(\mathrm{~d}, 1 \mathrm{H}, J=10 \mathrm{~Hz}, 1-\mathrm{H})$. HRMS $m / z$ : 504.2361 (Calcd for $\mathrm{C}_{27} \mathrm{H}_{36} \mathrm{O}_{9}: 504.2359$ ).

Compound 10 (20.1 mg, 98.2\%): $[\alpha]_{\mathrm{D}}+37.1^{\circ}(c=0.862$, $\left.\mathrm{CHCl}_{3}\right)$. IR $\left(\mathrm{CHCl}_{3}\right) \mathrm{cm}^{-1}: 3550(\mathrm{OH}), 1741,1661(\mathrm{C}=\mathrm{O})$, $1620,1600(\mathrm{C}=\mathrm{C}) .{ }^{1} \mathrm{H}-\mathrm{NMR}\left(\mathrm{CDCl}_{3}\right) \delta: 1.21(\mathrm{~s}, 3 \mathrm{H}, \mathrm{Me})$, $1.45(\mathrm{~s}, 3 \mathrm{H}, \mathrm{Me}), 3.70,3.77\left(\mathrm{~s}\right.$, each $\left.3 \mathrm{H}, \mathrm{CO}_{2} \mathrm{Me}\right), 4.39-$ $4.45(\mathrm{~m}, 1 \mathrm{H}, 11-\mathrm{H}), 5.11(\mathrm{~s}, 1 \mathrm{H}, 20-\mathrm{H}), 6.01(\mathrm{~d}, 1 \mathrm{H}, J=1.65$ $\mathrm{Hz}, 4-\mathrm{H}), 6.25(\mathrm{dd}, 1 \mathrm{H}, J=9.9,1.65 \mathrm{~Hz}, 2-\mathrm{H}), 7.23(\mathrm{~d}, 1 \mathrm{H}$, $J=9.9 \mathrm{~Hz}, 1-\mathrm{H})$. HRMS $m / z$ : $504.2360\left(\right.$ Calcd for $\mathrm{C}_{27} \mathrm{H}_{36} \mathrm{O}_{9}$ : $504.2359)$ was obtained by a reaction of $6(19.9 \mathrm{mg})$ and 
chlorotrimethylsilane $(9.7 \mathrm{mg})$ in dry $\mathrm{MeOH}(0.5 \mathrm{ml})$ under the same conditions as described above.

Methyl(20S/R)-9-fluoro-11 $\beta, 17,20$-trihydroxy-20methoxycarbonyl-1,4-pregnadien-3-one 20-Succinate (11/12) (20S)-Methyl succinate (11) (60.2 $\mathrm{mg}, 93.1 \%)$ : $[\alpha]_{\mathrm{D}}+53.4^{\circ}\left(c=2.20, \mathrm{CHCl}_{3}\right)$. IR $\left(\mathrm{CHCl}_{3}\right) \mathrm{cm}^{-1}: 3550$ $(\mathrm{OH}), 1742,1664(\mathrm{C}=\mathrm{O}), 1623,1607(\mathrm{C}=\mathrm{C}) .{ }^{1} \mathrm{H}-\mathrm{NMR}$ (CDCl3) $\delta: 0.85(\mathrm{~d}, 3 \mathrm{H}, J=7.3 \mathrm{~Hz}, \mathrm{Me}), 1.06(\mathrm{~s}, 3 \mathrm{H}, \mathrm{Me})$, $1.56(\mathrm{~s}, 3 \mathrm{H}, \mathrm{Me}), 3.71,3.75$ (s, each $\left.3 \mathrm{H}, \mathrm{CO}_{2} \mathrm{Me}\right), 4.30$ $4.38(\mathrm{~m}, 1 \mathrm{H}, 11-\mathrm{H}), 5.26(\mathrm{~s}, 1 \mathrm{H}, 20-\mathrm{H}), 6.11(\mathrm{~d}, 1 \mathrm{H}, J=$ $1.65 \mathrm{~Hz}, 4-\mathrm{H}), 6.32(\mathrm{dd}, 1 \mathrm{H}, J=9.9,1.65 \mathrm{~Hz}, 2-\mathrm{H}), 7.25(\mathrm{~d}$, $1 \mathrm{H}, J=9.9 \mathrm{~Hz}, 1-\mathrm{H}$ ). HRMS $\mathrm{m} / z: 536.2423$ (Calcd for $\mathrm{C}_{28} \mathrm{H}_{37} \mathrm{FO}_{9}:$ 536.2422) was obtained by a reaction of 7 (63.0 $\mathrm{mg})$ and chlorotrimethylsilane $(21.7 \mathrm{mg})$ in dry $\mathrm{MeOH}(2 \mathrm{ml})$ under the same conditions as described above.

$(20 R)$-Methyl succinate (12) $(97.5 \mathrm{mg}, 87.1 \%):[\alpha]_{\mathrm{D}}$ $+46.9^{\circ}\left(c=0.905, \mathrm{CHCl}_{3}\right)$. IR $\left(\mathrm{CHCl}_{3}\right) \mathrm{cm}^{-1}: 3550(\mathrm{OH})$, 1743, $1667(\mathrm{C}=\mathrm{O}), 1620,1607(\mathrm{C}=\mathrm{C}) .{ }^{1} \mathrm{H}-\mathrm{NMR}\left(\mathrm{CDCl}_{3}\right)$ $\delta: 1.11(\mathrm{~d}, 3 \mathrm{H}, J=6.9 \mathrm{~Hz}, \mathrm{Me}), 1.26(\mathrm{~s}, 3 \mathrm{H}, \mathrm{Me}), 1.58(\mathrm{~s}$, $3 \mathrm{H}, \mathrm{Me}), 3.70,3.76\left(\mathrm{~s}\right.$, each $\left.3 \mathrm{H}, \mathrm{CO}_{2} \mathrm{Me}\right), 4.26-4.34(\mathrm{~m}$, $1 \mathrm{H}, 11-\mathrm{H}), 5.14(\mathrm{~s}, 1 \mathrm{H}, 20-\mathrm{H}), 6.12(\mathrm{~d}, 1 \mathrm{H}, J=1.65 \mathrm{~Hz}, 4-$ H), 6.32 (dd, $1 \mathrm{H}, J=9.9,1.65 \mathrm{~Hz}, 2-\mathrm{H}), 7.17$ (d, $1 \mathrm{H}, J=9.9$ $\mathrm{Hz}, 1-\mathrm{H}$ ). HRMS m/z: 536.2421 (Calcd for $\mathrm{C}_{28} \mathrm{H}_{37} \mathrm{FO}_{9}$ : $536.2421)$ was obtained by a reaction of $8(109 \mathrm{mg})$ and chlorotrimethylsilane $(45.4 \mathrm{mg}$ ) in dry $\mathrm{MeOH}(4 \mathrm{ml})$ under the same conditions as described above.

Hydrolysis of (20S) Methyl Glycolate (3) A solution of $3(10 \mathrm{mg})$ in $\mathrm{MeOH}$ was treated with $2 \mathrm{~N} \mathrm{KOH}(0.05 \mathrm{ml})$ and the mixture was stirred for $2 \mathrm{~h}$ at room temperature. The mixture was acidfied by an addition of $10 \mathrm{~N} \mathrm{HCl}$, and then extracted with chloroform. The extract was washed with brine and dried $\left(\mathrm{MgSO}_{4}\right)$. Evaporation of the solvent left a residue which was purified by preparative thin layer chromatography (silica, $\mathrm{CHCl}_{3}: \mathrm{MeOH}=3: 2 \mathrm{v} / \mathrm{v}$ ) to give $13(5.5 \mathrm{mg}, 56.1 \%$ ): $[\alpha]_{\mathrm{D}}+43.6^{\circ}(c=0.055, \mathrm{MeOH})$. IR $\left(\mathrm{CHCl}_{3}\right) \mathrm{cm}^{-1}: 3550$ $(\mathrm{OH}), 1717,1662(\mathrm{C}=\mathrm{O}), 1600(\mathrm{C}=\mathrm{C}) .{ }^{1} \mathrm{H}-\mathrm{NMR}\left(\mathrm{CDCl}_{3}+\right.$ $\left.\mathrm{CD}_{3} \mathrm{OD}\right) \delta: 0.92(\mathrm{~d}, 3 \mathrm{H}, J=7.5 \mathrm{~Hz}, \mathrm{Me}), 1.26(\mathrm{~s}, 3 \mathrm{H}, \mathrm{Me})$, $1.57(\mathrm{~s}, 3 \mathrm{H}, \mathrm{Me})$. FAB-MS $m / z: 409\left(\mathrm{M}^{+}\right)$.

Croton Oil Ear Edema Bioassay Male Wistar rats (weighing 115-140 g SLC, Shizuoka, Japan) were randomly divided into thirteen groups, group of ten animals each. Effects of topically applied steroids on edema formation were measured using the croton oil-induced ear edema bioassay according to the procedure described previously. ${ }^{14)}$ Initial ear thickness of rats was measured and under light ether anesthesia, drug solution $(500 \mu \mathrm{g} / 40 \mu \mathrm{l})$ dissolved with $2 \%$ croton oil in acetone was applied to the outer and inner surface of the right ears, while the left ears were untreated. Control animals were treated with $2 \%$ croton oil in acetone alone. Six hours later, ear thicknesses were again measured, and the difference between right and left ear thickness was considered an index of edema formation. The percent inhibition of edema formation was determined from comparison of animals treated with each steroid derivative to the control animals. Dexamethasone was used as a reference compound.

Paper Disk Granuloma Bioassay The activity of steroids in this model was evaluated according to the method described by Tsurumi et al. ${ }^{15)}$ One group in the experiment consisted of six male Wistar rats (weighing $170-220 \mathrm{~g}$ ). Each steroid derivative $(250 \mu \mathrm{g})$ in ethanol was allowed to permeate in sterilized circular filter paper. Under ether anes- thesia, two steroid-treated papers were subcutaneously implanted into both dorsal regions of rats. Control animals were implanted with ethanol-treated papers. Eight days later, the rats were killed, and the papers and induced surrounding granulation tissue were recovered. After the papers were dried at $65^{\circ} \mathrm{C}$ for $48 \mathrm{~h}$, they were weighed and increment in papers weight was taken as an index of granuloma formation; reductions in granuloma were ascribed to local anti-inflammatory activity. Thymus and adrenal were isolated and weighed. Body weight gain was determined from the weight difference between before and after the experiment. Dexamethasone was used as a reference compound in paper disk granuloma bioassay.

Pharmacokinetics of Steroid Derivatives in Rats Dimethyl sulfoxide (DMSO)-isotonic sodium chloride solution $(1 \mathrm{ml}, 66: 33 \mathrm{v} / \mathrm{v})$ containing $40 \mu \mathrm{mol} / \mathrm{ml}$ steroid derivatives was bolus administered to the right subclavian vein in male Spraque-Dawley strain rats (weighing 263-305 g, SLC, Japan) under light ether anesthesia. Whole blood samples $(0.20 \mathrm{ml})$ were drawn at $2,5,10,30 \mathrm{~min}, 1,2,4$, and $6 \mathrm{~h}$ by venipuncture from the left subclavian vein under light ether anesthesia. Serum $(70 \mu 1)$ separated by centrifugation at $1250 \times g$ for $20 \mathrm{~min}$ and then was immediately frozen at $-80^{\circ} \mathrm{C}$ until HPLC analysis.

After serum $(50 \mu \mathrm{l})$ was mixed with acetonitrile $(100 \mu \mathrm{l})$, it was centrifuged at $2250 \times \boldsymbol{g}$ for $5 \mathrm{~min}$ and the supernatant $(20 \mu \mathrm{l})$ was passed through a $0.5 \mu \mathrm{m}$ filter (Millex-LH, Nihon Millipore, Ltd., Yonezawa, Japan) and injected into a HPLC column (Waters $8 \mathrm{C} 1810 \mu$ ) at a flow rate of $1.0 \mathrm{ml} /$ min with $20 \mathrm{~mm}$ phosphoric acid-acetonitrile $(45: 55 \mathrm{v} / \mathrm{v})$ as a mobile phase, supplemented by an UV detector set to $245 \mathrm{~nm}$. Measurement of the peak area ratio as a function of the prednisolone and dexamethasone concentrations was linear over the range $5-30 \mu \mathrm{g} / \mathrm{ml}$, and the limits of the detection were $0.1 \mu \mathrm{g} / \mathrm{ml}$. Measurement of the peak area ratio as a function of 3 and $\mathbf{1 3}$ concentrations was linear over the range $2.5-20$ and $6-24 \mu \mathrm{g} / \mathrm{ml}$, respectively, and the limits of the detection were 0.1 and $0.5 \mu \mathrm{g} / \mathrm{ml}$, respectively.

Parmacokinetic Analysis Pharmacokinetic parameters were found by moment analytical method. ${ }^{16)}$ In practice, the terminal elimination rate constant, $\beta$, for the concentrationtime curves after intravenous administrations was determined by linear regression of at least three data points from the terminal portion of the serum concentration-time plots. The area under the serum concentration-time curve after intravenous administration, $A U C$, was calculated using the logarithmic trapezoidal rule up to the final measured serum concentration $C_{\mathrm{p}}$ (last), and extrapolated to infinity by addition of the correction term $C_{\mathrm{p}}$ (last) $/ \beta$. AUMC, the area under the first moment curve to the last measured serum concentration after intravenous injection, was calculated with the linear trapezoidal rule, and addition of the correction term after the last measured point to the infinity, namely $t$ (last) $\cdot C_{\mathrm{p}}($ last $) / \beta+$ $C_{\mathrm{p}}($ last $) / \beta$. The terminal elimination half-life, $t_{1 / 2 \beta}$, was determined by dividing $\ln 2$ by $\beta$. MRT, the mean resident time, was obtained from $A U M C$ by $A U C$.

Statistical Analysis Statistical analysis was performed using Student's $t$-test or one-way analysis of variance supplemented with the multiple comparison procedure of Scheffe in the StatView ver. 4.5 program on Macintosh O.S., and a $p$ value of $<0.05$ was considered to be statistically significant. 
The protocols for animal experiments were previously approved by the Animal Research Committee, Akita University School of Medicine; all subsequent animal experiments adhered to the Guidelines for Animal Experimentation of the University.

\section{RESULTS AND DISCUSSION}

Topical anti-inflammatory effects of the synthesized steroid derivatives are screened using the croton oil-induced ear edema bioassay and paper disk granuloma bioassay, and the results were shown in Tables 1, 2 and 3. Systemic activities of their steroid derivatives were also evaluated by the normal body weights gain, and the relative weight of adrenal and thymus (Tables 2 and 3).

As shown in Table 1, among those tested, 2, 10, 7, 11 and dexamethasone inhibited edema formation on croton oil-induced ear edema in $69.3,75.0,79.6,89.2$ and $89.2 \%$, respectively, and showed almost the same anti-inflammatory activity as dexamethasone. As shown in Tables 2 and 3, none of the prepared steroid derivatives showed systemic side effects of adrenal, thymus, or body weight suppression, although dexamethasone induced their significant decrease. Compounds 7 and 11 which exhibited the strongest anti-inflammatory activities among these tested compounds were immediately hydrolyzed by esterase in rat serum and transformed into $\mathbf{3}$ and $\mathbf{1 3}$ within $2 \mathrm{~min}$ after intravenous administration. Each metabolite (3) was eliminated in mean half-lives of 0.786 to $0.866 \mathrm{~h}$, and $\mathbf{1 3}$ derived from $\mathbf{7}$ or $\mathbf{1 1}$ was eliminated in mean half-lives of 2.09 to $1.68 \mathrm{~h} . A U C_{0 \_\infty}$ of 3 derived from $\mathbf{7}$ showed about twice that of $\mathbf{3}$ derived from $\mathbf{1 1}$ (Table
4).

Compound 11 showed anti-inflammatory activity which equaled that of dexamethasone in rat ear edema (Table 1), whereas $\mathbf{7}$ and $\mathbf{1 1}$ exhibited relatively strong inhibitory effect in paper disk-induced granuloma among the synthesized compounds (Table 3). Metabolite 3 was somewhat inferior to dexamethasone in inhibition of granuloma and its systemic side effects were very few compared with dexamethasone. ${ }^{11)}$

It is obvious that relatively strong anti-inflammatory activity in both $\mathbf{1 1}$ and $\mathbf{7}$ are attributable to each metabolite $\mathbf{3}$, and

Table 1. Anti-inflammatory Effects of Steroid Derivatives on Croton Oil Induced Ear Edema in Rats

\begin{tabular}{clc}
\hline Compound & $\begin{array}{c}\text { Ear thickness } \\
\text { increase }(\%)\end{array}$ & $\begin{array}{c}\text { Mean inhibition } \\
(\%)\end{array}$ \\
\hline Prednisolone derivative & & \\
$\mathbf{1}$ & $13.2 \pm 2.8^{*}$ & 60.2 \\
$\mathbf{2}$ & $10.1 \pm 2.9^{* *}$ & 69.3 \\
$\mathbf{5}$ & $18.8 \pm 3.2$ & 43.0 \\
$\mathbf{6}$ & $13.1 \pm 2.7^{*}$ & 60.3 \\
$\mathbf{9}$ & $21.8 \pm 2.8$ & 34.1 \\
$\mathbf{1 0}$ & $8.28 \pm 1.89^{* *}$ & 75.0 \\
$\mathbf{3}$ & $14.0 \pm 2.6^{*}$ & 57.6 \\
$\mathbf{4}$ & $15.3 \pm 2.8^{*}$ & 53.7 \\
$\mathbf{7}$ & $6.76 \pm 1.35^{* *}$ & 79.6 \\
$\mathbf{8}$ & $16.9 \pm 2.8^{*}$ & 48.9 \\
$\mathbf{1 1}$ & $1.25 \pm 0.55^{* *}$ & 96.2 \\
$\mathbf{1 2}$ & $14.3 \pm 2.1^{*}$ & 56.7 \\
Dexamethasone derivative & $3.58 \pm 1.25^{* *}$ & 89.2 \\
\hline
\end{tabular}

Value represents the mean \pm S.E. of ten animals. Significant difference from control, $* p<0.05, * * p<0.01$.

Table 2. Effects of Subcutaneous Administration of Prednisolone on Paper Disk-Induced Granuloma in Rats

\begin{tabular}{|c|c|c|c|c|c|}
\hline \multirow{2}{*}{ Compound } & \multicolumn{2}{|c|}{ Granuloma } & \multicolumn{2}{|c|}{ Relative weight } & \multirow{2}{*}{$\begin{array}{l}\text { Body weight } \\
\text { gain } \\
\text { (g) }\end{array}$} \\
\hline & $\begin{array}{c}\text { Dry weight } \\
\text { (mg/100 g B.W.) }\end{array}$ & $\begin{array}{c}\text { Mean inhibition } \\
(\%)\end{array}$ & $\begin{array}{c}\text { Adrenal } \\
\text { (mg/100g B.W.) }\end{array}$ & $\begin{array}{c}\text { Thymus } \\
\text { (mg/100 g B.W.) }\end{array}$ & \\
\hline Control & $69.6 \pm 5.11$ & - & $18.8 \pm 0.6$ & $242 \pm 8$ & $67.0 \pm 1.4$ \\
\hline 1 & $52.0 \pm 1.6^{* *}$ & 25.3 & $20.0 \pm 0.8$ & $261 \pm 9$ & $67.6 \pm 2.3$ \\
\hline 2 & $93.2 \pm 18.2$ & -33.9 & $21.1 \pm 0.6^{*}$ & $257 \pm 10$ & $68.2 \pm 1.5$ \\
\hline 5 & $69.6 \pm 8.5$ & 0.0 & $19.4 \pm 0.6$ & $245 \pm 11$ & $64.2 \pm 1.5$ \\
\hline 6 & $59.9 \pm 3.6^{*}$ & 13.9 & $18.7 \pm 0.7$ & $268 \pm 13$ & $66.4 \pm 0.9$ \\
\hline 9 & $60.0 \pm 3.0$ & 13.8 & $19.4 \pm 0.4$ & $239 \pm 11$ & $67.5 \pm 1.9$ \\
\hline 10 & $59.8 \pm 2.1$ & 14.1 & $19.0 \pm 0.7$ & $240 \pm 7$ & $68.5 \pm 1.4$ \\
\hline Dexamethasone & $48.9 \pm 2.0^{* *}$ & 29.7 & $19.1 \pm 0.8$ & $66.2 \pm 8.4^{* *}$ & $51.0 \pm 1.0 * *$ \\
\hline
\end{tabular}

Value represents the mean \pm S.E. of ten animals. Significant difference from control, $* p<0.05, * * p<0.01$.

Table 3. Effects of Subcutaneous Administration of Dexamethasone on Paper Disk-Induced Granuloma in Rats

\begin{tabular}{|c|c|c|c|c|c|}
\hline \multirow{2}{*}{ Compound } & \multicolumn{2}{|c|}{ Granuloma } & \multicolumn{2}{|c|}{ Relative weight } & \multirow{2}{*}{$\begin{array}{l}\text { Body weight } \\
\text { gain } \\
\text { (g) }\end{array}$} \\
\hline & $\begin{array}{c}\text { Dry weight } \\
\text { (mg/100 g B.W.) }\end{array}$ & $\begin{array}{c}\text { Mean inhibition } \\
(\%)\end{array}$ & $\begin{array}{c}\text { Adrenal } \\
\text { (mg/100 g B.W.) }\end{array}$ & $\begin{array}{c}\text { Thymus } \\
\text { (mg/100 g B.W.) }\end{array}$ & \\
\hline Control & $98.8 \pm 14.9$ & - & $18.5 \pm 0.6$ & $273 \pm 5$ & $57.1 \pm 1.8$ \\
\hline 3 & $62.3 \pm 2.4^{*}$ & 36.9 & $18.8 \pm 0.8$ & $271 \pm 11$ & $59.0 \pm 1.6$ \\
\hline 4 & $71.6 \pm 2.8$ & 27.5 & $18.4 \pm 0.9$ & $262 \pm 13$ & $59.0 \pm 1.5$ \\
\hline 7 & $57.9 \pm 2.5^{*}$ & 41.4 & $17.8 \pm 0.5$ & $262 \pm 10$ & $56.6 \pm 1.6$ \\
\hline 8 & $68.5 \pm 3.6$ & 30.7 & $16.9 \pm 0.6^{*}$ & $249 \pm 12$ & $61.8 \pm 1.5$ \\
\hline 11 & $58.0 \pm 3.4^{*}$ & 41.3 & $19.7 \pm 0.4$ & $275 \pm 11$ & $56.3 \pm 2.0$ \\
\hline 12 & $66.9 \pm 4.0$ & 32.3 & $19.1 \pm 0.9$ & $290 \pm 14$ & $58.5 \pm 1.1$ \\
\hline Dexamethasone & $60.9 \pm 5.6^{*}$ & 38.4 & $16.3 \pm 0.4^{* *}$ & $51.5 \pm 4.5^{* *}$ & $47.6 \pm 1.4^{* *}$ \\
\hline
\end{tabular}

Value represents the mean \pm S.E. of ten animals. Significant difference from control, $* p<0.05, * * p<0.01$. 


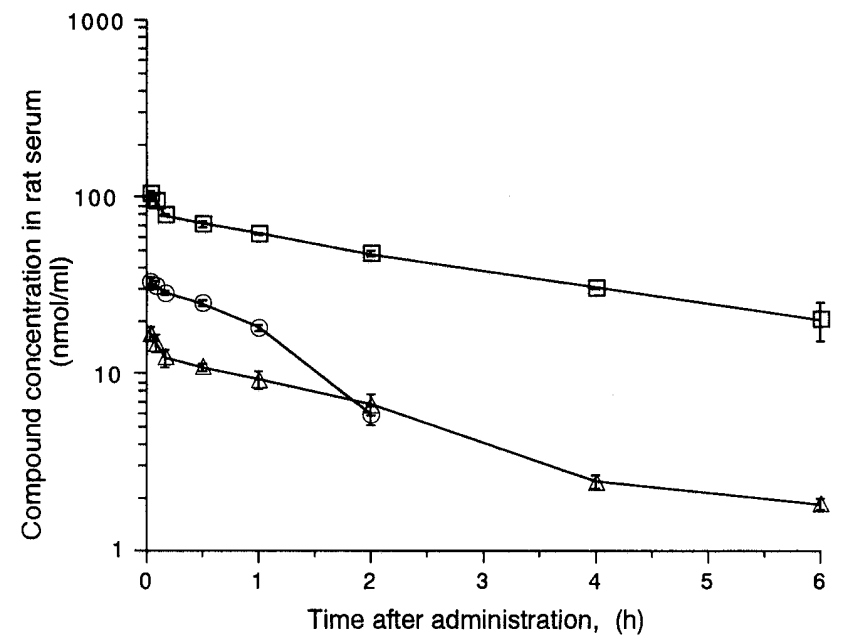

Fig. 1. Serum Concentration-Time Profile of the Metabolites after a Single Intravenous Administration of 7 in Rats

Key: $\bigcirc, 3 ; \Delta, 13 ; \square$, dexamethasone. Results are expressed as means \pm S.E. of three animals.

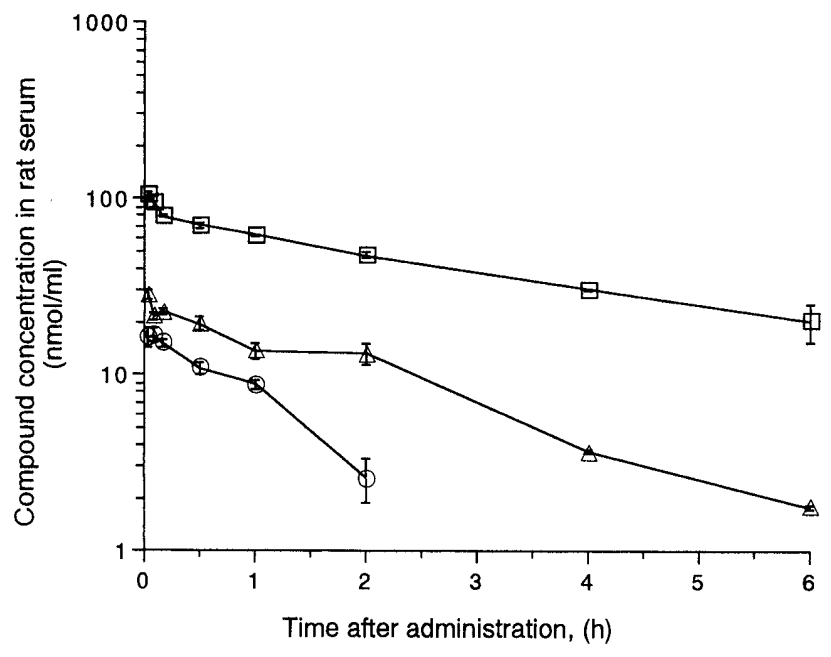

Fig. 2. Serum Concentration-Time Profile of the Metabolites after a Single Intravenous Administration of $\mathbf{1 1}$ in Rats

Key: $O, \mathbf{3} ; \triangle \mathbf{1 3} \square$, dexamethasone. Results are expressed as means \pm S.E. of three animals.

Table 4. Pharmacokinetic Behaviors of 7,11 and Their Metabolites after i.v. Administration in Rats

\begin{tabular}{|c|c|c|c|c|c|c|c|}
\hline \multirow{2}{*}{ Parameter } & \multirow{2}{*}{7} & \multirow{2}{*}{11} & \multicolumn{2}{|c|}{ Metabolites from 7} & \multicolumn{2}{|c|}{ Metabolites from 11} & \multirow{2}{*}{ Dexamethasone } \\
\hline & & & 3 & 13 & 3 & 13 & \\
\hline$A U C_{0-\infty}(\mathrm{nmol} \cdot \mathrm{h} / \mathrm{ml})$ & N.D. & N.D. & $44.9 \pm 1.6^{*}$ & $38.2 \pm 2.3^{*}$ & $22.7 \pm 2.1^{*}$ & $65.7 \pm 6.5^{*}$ & $358 \pm 49$ \\
\hline$M R T_{0-\infty}(\mathrm{h})$ & N.D. & N.D. & $1.10 \pm 0.02 *$ & $2.82 \pm 0.29$ & $1.23 \pm 0.25^{*}$ & $2.44 \pm 0.36^{* *}$ & $4.58 \pm 0.92$ \\
\hline$t_{1 / 2}(\mathrm{~h})$ & N.D. & N.D. & $0.786 \pm 0.007^{*}$ & $2.09 \pm 0.23$ & $0.866 \pm 0.193^{*}$ & $1.68 \pm 0.32^{* *}$ & $3.23 \pm 0.66$ \\
\hline
\end{tabular}

Each value represents mean \pm S.E. of three experiments. $*$ Significant difference from dexamethasone at $p<0.05 . \quad * *$ Significant difference from dexamethasone at $p<0.01$. N.D., compound was not detected in serum.

that the more active anti-inflammatory activity of $\mathbf{1 1}$ depends on its high lipophilic character compared to carboxylic acid (7). Compound 11 could penetrate the skin and accumulate at the inflammatory site more readily than 7 .

In our study, none of the suppressions of adrenal, thymus or body weight were observed in $\mathbf{7}$ and $\mathbf{1 1}$ although dexamethasone reduced the thymus weight by $81 \%$ (Table 3 ). Compounds $\mathbf{7}$ and $\mathbf{1 1}$ were promptly metabolized in systemic blood and tissue to 3 , which was further hydrolyzed to provide inactive form 13 (Figs. 1 and 2) as well as metabolism of prednisolone analogue (1) to the corresponding inactive carboxylic acid. ${ }^{4)}$

Comparison of the inhibitory effects between edema from croton oil induced ear edema and granuloma from paper disk-induced granuloma in rats, showed the effect of 7 to be the same as that of $\mathbf{1 1}$ in the paper disk method, though the activity of $\mathbf{1 1}$ in croton oil edema was stronger than that of $\mathbf{7}$ (Tables 1 and 3). The reason for the difference may be that 7 produce more effectively active metabolite 3 than 11, as shown in Table 4. In fact, 3 possessed novel inhibitory activity in granuloma proliferation in the paper disk method. In this disk method, it seems that the paper disk is influenced by the invasion of biological fluids containing various enzymes from surrounding tissues over a long period., the experiment of croton oil induced ear edema, on the other hand, a penetration of drug into skin may be important for expression of the activity, and a drug in solvent (croton oil and acetone) which exists outside of the ear will not be easily influenced by biological fluids.
Although we were able to find promising new steroids in this study, only one dosage could be prepared in our two experiments for anti-inflammatory activity. To determine the pharmacological strength between dexamethasone and potent new steroids, studies of their dose-response curves will be necessary in the future, and plasma corticosteroids must be monitored during administration of any new steroids developed to ensure they have no side effects.

The more potent a steroid is the greater the side effect will be when administration is abruptly stopped. For instance, in the case of cutaneous vessels, rebound vasodilatation is probable. This is because the potency of a topical steroid is judged by this vasoconstrictive effect. ${ }^{17)}$ Other side effects also tend to be seen, particularly with fluorinated steroids. ${ }^{18,19)}$ Cases in which the hypothalamic-pituitary-adrenal axis is present require the most attention, ${ }^{20)}$ since, there is severe risk because the amount of glucocorticoid secreted decreases. Although it is expected that $\mathbf{7}$ and $\mathbf{1 1}$ will eliminate this risk for systemic symptoms in human owing to the experimental results in rats (Tables 3 and 4), it may be necessary to pay attention to local side effects such as vascular, dermal and epidermal effects.

Betamethasone 17-valerate and other potent fluoride steroids are currently in wide use as topical steroids. However, though less betamethasone 17-valerate is absorbed when applied externally than when administered orally, its half-life is reported to be twice as long in the former use. ${ }^{21)}$ The widespread of fluoride steroid on the skin was absorbed into systemic blood. ${ }^{22)}$ These facts suggest that it is highly 
likely that long-term administration and widespread application of current fluoride steroids cause systemic adverse effects. ${ }^{20)}$ In our study, 7 and $\mathbf{1 1}$ were quickly distributed from the systemic blood to tissue, and could no longer be detected in rat blood (Figs. 1 and 2). The $M R T_{0-\infty}$ of 3 for 7 and 11 was on average a mere 1.10 and $1.23 \mathrm{~h}$, respectively, suggesting that these compounds rapidly metabolize to 3 in rats (Table 4). At least, these findings suggest that there is no accumulation of active bodies in rat blood for long-term application. If 7 and $\mathbf{1 1}$ rapidly metabolize in human as well as rats, they are expected to be safer than the currently used fluoride steroids in cases of widespread and long-term application.

Among our synthesized steroids, 7 and 11 possess an antiinflammatory potency when applied locally, but do not have side effects in major organs. These findings suggest that 7 and 11 might be candidates as the novel steroids, and that introduction of the succinyl group into the methyl glycolates at $\mathrm{C}-20$ is useful to a avoid suppression of major organs due to the side effects of corticosteroids.

\section{REFERENCES}

1) Smith M. D., J. Chromatogr., 164, 129-137 (1979).

2) Iwasaki E., Clin., Chem., 33, 1412-1415 (1987).

3) Iwasaki E., Baba M., Arerugi, 42, 1555-1562 (1993).

4) Lee H. J., Soliman M. R. I., Science, 215, 989-991 (1982).

5) Lee H. J., Khalil M. A., Lee J. W., Drug Exptl. Clin. Res., X, 835-844
(1984).

6) Heiman A. S., Taraporewala I. B., McLean H. M., Hong D., Lee H. J., J. Pharm. Sci., 79, 617-621 (1990).

7) McLean H. M., Khalil M. A., Heiman A. S., Lee H. J., J. Pharm. Sci., 83, 476-480 (1994).

8) Kimura T., Yamaguchi T., Usuki K., Kurosaki Y., Nakayama T., Fujiwara Y., Matsuda Y., Unno K., Suzuki T., J. Controlled. Release., 30, 125-135 (1994).

9) Scheuplein R. J., Blank I. H., Brauner G. J., Dorothy J., MacFarlane A. B., J. Invest. Dermatol., 52, 63-70 (1969).

10) Sugawara T., Nippon Hihukagakukai Zasshi, 70, 777-792 (1960).

11) Hong S. U., Park K. H., Chae J. S., Lee J. W., Kim C. S., Kim J. K., Drug Exptl. Clin. Res., XV, 511-520 (1989)

12) Lewbart M. L., Mattox V. R., J. Org. Chem., 28, 1779-1786 (1963).

13) Kimura T., Yamaguchi T., Usuki K., Kurosaki Y., Nakayama T., Fujiwara Y., Unno K., Suzuki T., Drug Delivery System, 6, 375-379 (1991).

14) Yamada K., Hattori S., Hakoda T., Miyazaki M., Tho T., Furukawa T., Nippon Yakurigaku Zasshi, 75, 789-798 (1979).

15) Tsurumi K., Kyuki K., Niwa M., Maki E., Fujimura H., Oyo Yakuri, 24, 85-103 (1982).

16) Yamaoka K., Nakagawa T., Uno T., J. Pharm. Biopharm., 6, 547-558 (1978).

17) McKenzie A. W., Stoughton R. B., Arch. Dermatol,, 88, 608-615 (1962).

18) Epstein N. N., Epstein W. L., Epstein J. H., Arch Dermatol., 87, 450457 (1963).

19) Fisher L. B., Maibach H. I., Arch. Dermatol., 103, $39-44$ (1971).

20) Feiwel M., James V. H. T., Barnett E. S., Lancet, 1, 485-487 (1969).

21) Kubota K., Huttinot E. S. L. G., Andersen P. H., Maibach H. I., Br. J. Clin. Pharmacokinet., 37, 86-88 (1994).

22) Mizuchi A., Miyachi Y., Tamaki K., Kukita A., J. Invest. Dermatol., 67, 279-282 (1976). 